\title{
Ekologi Budaya Suku Bajau dalam Novel Mata dan Manusia Laut Karya Okky Madasari
}

\author{
Noviatussa'diyah $^{1}$, Sugiarti ${ }^{2}$, Eggy Fajar Andalas ${ }^{3}$ \\ Pendidikan Bahasa Indonesia, Universtas Muhammadiyah Malang \\ noviopi15opi@gmail.com ${ }^{1}$, atika umm@yahoo.co.id ${ }^{2}$, ef andalas@yahoo.com ${ }^{3}$
}

DOI: $\underline{\text { https://doi.org/10.32528/bb.v6i1.3780 }}$

First received: 07-11-2020

Final proof received: $24-02-2021$

\begin{abstract}
ABSTRAK
Novel Mata dan Manusia Laut karya Okky Madasari menggambarkan bentuk relasi antara manusia dengan lingkungan serta ekologi budaya masyarakat pesisir. Adapun penelitian ini bertujuan untuk mendeskripsikan (1) gambaran ekologi budaya masyarakat daerah pesisir (2) bentuk relasi antara manusia dan lingkungan (3) dampak relasi manusia dan lingkungan dalam novel Mata dan Manusia Laut karya Okky Madasari. Metode yang digunakan adalah deskriptif kualitatif. Pendekatan yang dilakukan adalah pendekatan ekologi budaya. Sumber data yang digunakan adalah novel Mata dan Manusia Laut karya Okky Madasari. Data berupa narasi dan dialog tokoh dalam novel Mata dan Manusia Laut karya Okky Madasari. Untuk mendapatkan data tersebut dilakukan dengan menggunakan teknik baca catat. Maksud dari teknik baca catat yaitu membaca keseluruhan novel, kemudian mencatat hal-hal yang berkaitan dengan ekologi budaya atau objek penelitian. Adapun analisis data yang dilakukan diantaranya adalah mengklasifikasi data, mengkategori data dan menemukan permasalahan penting yang berkaitan dengan perspefktif ekologi budaya yang ada pada masyarakat pesisir khususnya wilayah pesisir suku Bajau. Hasil penelitian ini menunjukkan bahwa terdapat (1) gambaran ekologi budaya masyarakat darah pesisir (2) bentuk relasi antara manusia dan lingkungan (3) dampak relasi antara manusia dan lingkungan. Relasi-relasi yang mengakibatkan munculnya sebuah dampak positif maupun negatife harus terus diperhatikan agar mencapai ekologi budaya yang ideal.
\end{abstract}

Kata kunci: ekologi budaya ; relasi ; dampak; novel

\begin{abstract}
The novel Mata dan Manusia Laut by Okky Madasari describes the form of the relationship between humans and the environment as well as the cultural ecology of coastal communities. This study aims to describe (1) the ecological picture of the coastal community culture (2) the form of the relationship between humans and the environment (3) the impact of human and environmental relations in Okky Madasari's novel Mata dan Manusia Laut. The method used is descriptive qualitative. The approach taken is a
\end{abstract}


cultural ecology approach. The data source used was the novel Mata dan Manusia Laut by Okky Madasari. The data is in the form of narrative and character dialogue in Okky Madasari's Mata and Manusia Laut. To get this data, it is done by using the reading note technique. The purpose of the reading note technique is to read the entire novel, then note things related to cultural ecology or the object of research. The data analysis carried out included classifying the data, categorizing the data and finding important problems related to the cultural ecological perspective that exists in coastal communities, especially the coastal areas of the Bajau tribe. The results of this study indicate that there are (1) an ecological picture of the coastal blood community culture (2) the form of the relationship between humans and the environment (3) the impact of the relationship between humans and the environment. Relationships that result in the emergence of a positive or negative impact must continue to be considered in order to achieve an ideal cultural ecology.

\section{Keywords: cultural ecology; relationships; impacts; novels}

\section{PENDAHULUAN}

Sastra dan lingkungan alam merupakan dua komponen yang tidak terpisahkan. Keduanya sama-sama memiliki pengaruh satu sama lain. Dalam penciptaan sebuah karya sastra, kebanyakan dari pengarang memperoleh inspirasi dari lingkungan alam sekitar untuk dituliskan dalam karya sastra. Kehadiran sastra memiliki hubungan yang kuat dengan lingkungan alam, sosial, dan budaya. Berdasarkan pernyataan tersebut, sudah sangat jelas bahwa lingkungan budaya berperan sebagai inspirasi pengarang untuk menciptakan sebuah karya sastra (Sugiarti, 2019).

Indonesia merupakan negara yang kaya akan budaya dengan berbagai wilayah yang ada di dalamnya. Setiap wilayah memiliki kebudayaan yang berbeda, mulai dari wilayah pedesaan yang memiliki kebiasaan bercocok tanam di sawah dengan padi sebagai tanaman pokok, wilayah pesisir berdasarkan mata pencaharian sebagai nelayan dan membangun tempat tinggal disekitar laut, dan wilayah perkebunan berdasarkan sistem berkebun dengan memiliki tanaman pokok berupa keladi dan ubi jalar (Sudikan, 2016:171). Hal tersebut sesuai dengan kehidupan yang dijalani oleh masyarakat suku Bajau saat ini. Suku Bajau merupakan salah satu suku di Indonesia yang melakukan hidup secara nomaden di atas laut sekitar wilayah pesisir.

Suku Bajau terkenal dengan kemampuan melautnya yang sangat baik. Selain itu, suku Bajau memiliki sistem etika dan budaya sendiri. Sebagai manusia yang menggantungkan kehidupan pada lingkungan alam mereka memiliki budaya yang mencakup berbagai aturan yang dihasilkan dari pengalam dan spritualitas. Komunitas Bajau yang bertempat tinggal di daerah pesisir memiliki kedekatan emosional terhadap sumber daya alam yang menghasilkan perilaku nyata mempertimbangkan ekologis dalam kehidupan mereka sehari-hari. Komunitas Bajau memiliki kearifan berupa tradisi, aturan atau pantangan turun temurun yang ditaati masyarakat Bajau demi menjaga kelestarian wilayah pesisir sebagai sumber kehidupan mereka. Sumber daya alam laut menjadi 
sumber penghidupannya, masyarakat Bajau sangat menghormati dan menghargai laut karena laut bagi mereka merupakan sumber penghidupannya. Masyarakat Bajau tidak ada yang berani menentang pamali, karena sudah berkeyakinan penuh apabila ada salah seorang berani melanggar pamali maka akan mendapat malapetaka yang berupa tidak memperoleh ikan, badai, ombak besar, dsb (Artanto, 2017).

Novel Mata dan Manusia Laut merupakan buku ketiga serial novel anak-anak yang ditulis oleh Okky Madasari. Novel Mata dan Manusia Laut sangat kental membahas tentang gambaran ekologi budaya masyarakat pesisir Suku Bajau. Melalui novel ini, Okky Madasari mengungkapkan bahwa relasi antara sastra dan kebudayaan mendapatkan perhatian khusus. Adanya relasi antara manusia dengan alam sekitar yang digambarkan melalui seorang tokoh Bambulo, mampu terselamatkan saat ia mendapati musibah di tengah laut akibat melanggar kepercayaan yang telah lama disepakati oleh masyarakat suku Bajau. Rasa penasaran tokoh menimbulkan pengalaman yang membangkitkan kesadaran tokoh untuk memahami kearifan lokal yang telah dipercayai secara turun menurun. Hubungan alam dan budaya memiliki kaitan yang sangat erat. Alam dan budaya merupakan dua buah komponen yang saling berkelindihan satu dengan yang lain (Sugiarti, 2019).

Setiap manusia yang berada pada suatu lingkungan pasti akan melakukan sebuah interaksi. Interaksi tersebut terjadi tidak hanya sesama manusia, akan tetapi juga bisa terhadap lingkungan sekitar. Adanya interaksi yang terjadi antara sesama manusia, manusia dengan lingkungan akan menghasilkan sebuah kebiasaan atau bisa menjadi sebuah aturan yang disebut dengan kebudayaan. Setiap kebudayaan memiliki cara yang berbeda-beda sesuai dengan kebutuhan masyarakatnya. Pada dasarnya, interaksi kehidupan manusia tidak hanya menghasilkan sebuah kebudayaan, akan tetapi dalam pemenuhan kebutuhan manusia juga diperlukan adanya budaya. (Sugiarti, dkk 2019:69).

Lingkungan sering digambarkan melalui beberapa media, salah satu contohnya adalah melalui karya sastra yang berupa novel. Hal ini selaras dengan pemikiran Quick dalam Endaswara (2016) yang mengungkapkan bahwa novel merupakan fiksi yang banyak melukiskan lingkungan, tidak ada satupun novel yang tidak terkait dengan lingkungan. Lingkungan memiliki peranan penting. Oleh karena itu, ekokritisme dapat diterapkan dalam novel. Ekokritisme merupakan disiplin ilmu baru. Ilmu ini akan mempelajari tentang hubungan manusia dengan lingkungan fisik. Pengkaji sebagai seseorang yang mengkaji ekokritik novel akan mengetahui hubungan antara sastra dan alam atau lingkungan melalui berbagai pendekatan. Model kajian ekokritik sastra sendiri memiliki dua model yaitu model kajian sastra lingkungan dan model kajian etis. Kajian berperspektif sastra (lingkungan) dalam ekokritik dapat mengontruksi paras sastra (kearifan) lingkungan, sedangkan kajian yang berperspektif etis dapat menggambarkan nilai-nilai kearifan terhadap lingkungan (Sukmawan, 2008:2).

Perkembangan zaman akan mempengaruhi perubahan interaksi yang terjadi di masyarakat. Adanya perubahan tersebut tentunya juga berpengaruh pada budaya-budaya 
yang telah ada dalam suatu masyarakat. Interaksi yang terjadi antara manusia dengan lingkungan pun juga akan berpengaruh yang dapat menimbulkan ketidakselarasan ekologi. Hal ini manusia sebagai makhluk hidup yang tinggal dan menggantungkan terhadap lingkungannya pasti memiliki pengaruh besar yang mengakibatkan perubahan lingkungan serta timbulnya ketidakselarasan ekologi. Manusia dalam perubahannya tidak bisa jauh dari yang namanya sebuah budaya untuk dijadikan dasar keputusan bertingkah laku. Masyarakat dan kebudayaan yang menyertainya memiliki potensi besar untuk untuk terwujudnya kebudayaan nasional Indonesia (Sugiarti, 2018).

Kaitan antara ekosistem dengan budaya dapat kita sebut dengan ekologi budaya. Istilah ekologi budaya terdiri dari dua pengertian menurut bahasa yaitu ekologi yang memiliki arti sebuah cabang ilmu dimana dalam kajiannya difokuskan pada konteks sumber daya alam, dan budaya pada konteks ini diartikan sebagai sistem pengetahuan manusia sebagai makhluk sosial. Jadi dapat disimpulkan bahwa ekologi budaya adalah suatu pengetahuan yang dimiliki oleh manusia sebagai makhluk sosial dalam memahami dan menginterpretasi lingkungan alam (Sudikan, 2016:167). Mengenai hal ini, ekologi tidak hanya membahas tentang ekosistem atau alam, tapi juga dapat digunakan untuk mengkaji bidang lainnya seperti sastra. Dalam hubungannya dengan kajian sastra, pemakaian istilah ekologi digunakan dalam pengertian yang beragam. Pertama, pengertian ekologi dalam konteks ekologi alam. Dalam kajian ekologi alam jga terdapat 2 ragam ekologi alam, yaitu kajian ekologi yang menekankan aspek alam sebagai inspirasi sebuah karya sastra dan kajian ekologi yang menekankan pembelaan terhadap kerusakan lingkungan akibat ulah manusia. Kedua, pengertian ekologi dalam konteks ekologi budaya yang ditentukan oleh pola hidup dan perbedaan karakteristik setiap wilayah (Endaswara, 2016).

Penerapan ekologi budaya dalam sastra dilakukan dengan beroperasinya budaya dalam kehidupan manusia yang menjadi kunci utama dengan bertumpu pada pemikiran Koentjaraningrat tentang unsur kebudayaan dan wujud kebudayaan. Ilmu ekologi dan sastra dapat sejalan karena sastra mengungkap peristiwa-peristiwa yang terjadi dan melibatkan lingkungan sebagai objek kajiannya (Sugiarti, 2017:11). Dalam kerangka unsur kebudayaan dan wujud budaya sebagai satu kesatuan dapat digambarkan dengan penyatuan manusia dengan lingkungan dan budaya yang menyertainya dapat terwadahi. Adapun hubungan antara lingkungan dan beberapa sistem yang terkait dengan ekologi budaya diantaranya adalah lingkungan dan sistem mata pencaharian, serta lingkungan dan sistem kekerabatan (Sugiarti, dkk., 2019:79). Masyarakat yang berada di suatu daerah memiliki sistem mata pencaharian yang berbeda-beda sesuai dengan daerah yang ditinggali. Daerah pesisir merupakan sebuah daerah yang berada di kawasan perairan, apabila dilihat dari letak dearahnya sudah sangat jelas bahwa mata pencaharian yang ditekuni oleh masyarakat pesisir adalah menangkap ikan. Sama halnya dengan cerita yang terdapat dalam novel Mata dan Manusia Laut diceritakan bahwa mata pencaharian masyarakat suku Bajau adalah menangkap ikan. 
Sistem kepercayaan merupakan suatu keyakinan yang dipegang oleh masyarakat. Masyarakat mempercayai dan meyakini bahwa ada kekuatan yang lebih tinggi dari manusia, yaitu kekuatan supranatural. Emosi keagamaan bertumpu pada aktivitas manusia yang berkaitan dengan religi, seperti pada upacara keagamaan. Dalam sistem upacara keagamaan memiliki empat aspek yaitu : (1) lokasi upacara (2) pelaksanaan upacara (3) alat-alat upacara yang disiapkan (4) pemimpin dan orang yang melakuakan upacara (Koentjaraningrat, 2002:376-377).

Interaksi antar kelompok masyarakat merupakan sebuah bentuk interaksi manusia dengan lingkungannya dalam mencari sebuah penghidupan. Tiap kelompok masyarakat memiliki pola penghidupan yang berbeda. Hal tersebut berdasarkan pada perbedaan ekologi dan budaya suatu kelompok masyarakat terentu (Kristiawan, 2017). Beberapa keunikan budaya yang dimiliki oleh masyarakat Bajau, menjadi inspirasi penulis Okky Madasari untuk menuliskan novel Mata dan Manuisa Laut. Selain itu, novel ini menarik untuk dikaji, karena sebagai pembaca mendapatkan pengetahuan tentang budaya suku Bajau, juga dapat menemukan gambaran mengenai ekologi budaya masyarakat pesisir yang diperankan oleh seorang tokoh bernama Bambulo sebagai masyarakat asli suku Bajau dan Matara sebagai masyarakat wilayah perkotaan yang mencoba berkunjung ke daerah pesisir. Ekologi budaya tentunya sangat penting bagi kehidupan kita, karena selain sebagai bentuk perkembangan suatu ekosistem, ekologi budaya juga dapat digunakan untuk pelestarian alam dan membangun pemikiran masyarakat terhadap ekosistem yang ada.

Penelitian yang berkaitan dengan ekologi budaya dalam novel Mata dan Manusia Laut karya Okky Madasari belum pernah dilakuakan oleh siapapun. Akan tetapi penelitian yang berkaitan dengan ekologi budaya sudah pernah dilakukan dengan bahan kajian yang berbeda. Pertama, penelitian yang dilakukan oleh Putra dan Sugiarti (2019) tentang "Ekologi Budaya dalam Novel Lanang karya Yonathan Rahardjo". Hasil penelitian menunjukkan adanya dinamika dalam ekologi budaya melalui tindakan yang dilakukan oleh manusia untuk memenuhi kebutuhannya baik secara tradisional dan modern. Adapun beberapa sub bab yang terdapat dalam jurnal terkait dengan hasil penelitian ekologi budaya dalam novel Lanang adalah [1] representasi unsur budaya dalam novel Lanang [2] pemertahanan yang tradisional dan modern [3] hubungan timbal balik manusia dan lingkungan [4] dinamika lingkungan budaya : penyatuan yang tradisional dan modern. Selanjutnya penelitian yang terkait dengan ekologi budaya juga pernah dilakukan oleh Sugiarti (2017) dengan judul "Kajian Ekobudaya dalam Novel Tirai Menurun karya NH. Dini”. Peneliti mampu mendeskripsikan fakta-fakta budaya dan tata nilai budaya Jawa yang ada dalam novel Tirai Menurun karya NH. Dini. Faktafakta budaya Jawa dalam novel Tirai Menurun mencakup segala aktivitas tokoh terkait dengan adat istiadat yang berlaku dalam masyarakat. Untuk tata nilai budaya Jawa dijadikan standar dalam menjalani hidup sehingga diperoleh kesatuan dan keselarasan. Nilai-nilai budaya telah ditanamkan oleh keluarga dalam diri tokoh untuk menjalani kehidupan sehari-hari. 
Penelitian ini memiliki perbedaan dengan penelitian sebelumnya yang terfokus pada ekologi budaya. Pada penelitian novel Mata dan Manusia Laut karya Okky Madasari tidak hanya menggambarkan bentuk dari ekologi budaya itu sendiri, akan tetapi juga memberikan penjelasan mengenai bagaimana relasi serta dampaknya antara manusia, lingkungan, dan budaya. Maksud dari relasi itu sendiri adalah sebuah hubungan yang terkait antara manusia, lingkungan alam dan budaya. Adanya relasi dari ketiga hal tersebut menghasilkan sebuah dampak positif maupun negatif terhadap diri manusia itu sendiri atau lingkungan alam sekitar. Seperti petuah-petuah yang sudah biasa diucapkan mengenai hukum alam yaitu lingkungan alam memiliki norma-norma yang harus dipatuhi oleh manusia, apabila manusia tersebut tidak mematuhi dan melanggar norma maka manusia tersebut akan dikucilkan atau lebih sederhananya bisa dikatakan alam akan membuat manusia tersebut tidak bisa bertahan lama dan binasa (Hariyono dan Aryati, 2018).

Berdasarkan uraian dan latar belakang di atas, masalah yang menjadi fokus dalam penelitian ini adalah gambaran ekologi budaya masyarakat pesisir melalui bentuk-bentuk budaya kepercayaan yang menonjol dalam novel Mata dan Manusia Laut. Tujuannya adalah untuk menunjukkan gambaran ekologi budaya masyarakat pesisir melalui bentukbentuk budaya kepercayaan yang menonjol. Selain itu, juga memberikan gambaran mengenai bentuk relasi manusia dengan lingkungan serta dampak relasi tersebut. Relasi yang terjadi saling pengaruh antar manusia dan lingkungan yang ternyata mengalami ketimpangan, yaitu pelanggaran budaya kepercayaan yang telah diyakini secara turun menurun dan mengakibatkan mala petaka untuk yang melakukannya.

\section{METODE PENELITIAN}

Penelitian ini menggunakan metode deskriptif kualitatif, yaitu sebuah penelitian yang dilakukan dengan mengeksplorasi fenomena lingkungan budaya yang digambarkan dalam novel Mata dan Manusia Laut. Pendekatan yang digunakan adalah pendekatan ekologi budaya. Sumber data penelitian ini adalah novel Mata dan Manusia Laut karya Okky Madasari. Data penelitian berupa kutipan-kutipan di dalam novel yang merepresentasikan gambaran ekologi budaya. Teknik pengumpulan data yang digunakan adalah teknik baca catat. Maksud dari teknik baca catat yaitu membaca keseluruhan novel, kemudian mencatat hal-hal yang berkaitan dengan ekologi budaya atau objek penelitian. Adapun analisis data yang dilakukan diantaranya adalah mengklasifikasi data, mengkategori data dan menemukan permasalahan penting yang berkaitan dengan perspefktif ekologi budaya yang ada pada masyarakat pesisir khususnya wilayah pesisir suku Bajau. 


\section{PEMBAHASAN}

Bentuk budaya masyarakat suku Bajau dalam Novel Mata dan Manusia Lau karya siapa

\section{Tradisi Duata untuk Pengobatan Masyarakat Suku Bajau}

Ekologi budaya tidak pernah terlepas dari sebuah kebudayaan. Kebudayaan sendiri memiliki beberapa unsur pembangun di dalamnya. Adapun beberapa unsur pembangun sebuah kebudayaan yaitu sistem religius dan mata pencaharian (Sugiarti, 2019:117). Okky Madasari dalam penulisan novelnya pun tidak terlepas menggambarkan dua unsur kebudayaan tersebut, karena sudah dijelaskan bahwa kebudayaan merupakan salah satu sebuah cerminan bagi seroang pengarang untuk menghasilkan karya-karyanya. Adapun penjelasan dari masing-masing unsur budaya yang terdapat dalam novel Mata dan Manusia Laut.

Pertama, religious atau kepercayaan. Religiusitas atau kepercayaan berkaitan dengan batin seorang manusia atau sekelompok manusia terhadap Tuhan Yang Maha Esa. Tidak hanya terhadap Tuhan Yang Maha Esa, kepercayaaan juga bisa dikonsepsikan sebuah keyakinan terhadap sesuatu yang lebih tinggi darinya sebagai manusia, seperti terhadap dewa-dewa, makhluk halus (roh-roh para leluhur), dewa tertinggi sebagai pencipta alam (Firmansyah dan Putrisari, 2017). Sebuah kepercayaan akan terus ada dalam sebuah kelompok masyarakat dan menjadi kepercayaan yang turun-menurun, dengan adanya kepercayaan tersebut juga akan menjadi sebuah norma yang harus ditaati dan dilakukan oleh sebuah masyarakat. Adapun bentuk budaya yang berkaitan dengan unsur kepercayaan di dalam novel Mata dan Manusia Laut diantaranya adalah tradisi Duata. Duata sendiri merupakan sebuah adat dan sudah menjadi kepercayaan bagi masyarakat suku Bajau untuk dilakukan apabila ada salah satu anggota dari keluarga mereka mengalami sebuah sakit yang tak kunjung sembuh.

Sanro kembali meyerahkan Nabila pada bapak Bambulo sambil berkata, "Duata." Bambulo tahu apa maksud Sanro. Duata sering dilakukan di kampung ini. Semua orang yang sakit akan diobati dengan duata, terutama jika itu sakit yang tak sembuh-sembuh. Namun Bambulo tak pernah membayangkan hal seperti ini aka terjadi pada keluarganya. Sepanjang hidup Bambulo, penyakit yang datang ke rumahnya tak lebih perkara flu, batuk, atau diare. Semuanya bisa sembuh dalam hitungan hari (Madasari, 2019:26).

Masyarakat suku Bajau memiliki tetuah yang bernama Sanro. Sanro telah dipercayai oleh masyarakat suku Bajau sebagai seseorang yang selalu membawa kabar baik atau buruk yang sedang terjadi di desa Sama. Untuk masalah kesehatan pun masyarakat suku Bajau lebih percaya kepada Sanro daripada dokter. Sistem kepercayaan yang kuat sudah tertanam dalam masyarakat suku Bajau sejak dulu sampai saat ini. Konsepsi sebuah kepercayaan merupakan suatu hal yang meyakini terhadap hal-hal yang ghaib seperti roh-roh yang sudah tiada. Berdasarkan pemikiran di atas, masyarakat Suku Bajau percaya terhadap tradisi Duata yang dilakukan dengan mengirimkan beberapa 
bentuk sesajen dan doa-doa untuk saudara kembar seseorang yang mengalami kesakitan untuk diberi kesembuhan yang dipimpin langsung oleh. Religiusitas atau kepercayaan menjadi sebuah aspek yang sangat penting. Masyarakat suku Bajau memiliki kepercayaan tersendiri mengenai cara pengobatan yang mereka lakukan secara tradisional.

Seiring dengan perkembangan zaman yang sangat modern ini, kebudayaan yang berada di Indonesia mengalami degradasi yang cukup memprihatinkan. Hal tersebut dipengaruhi karena adanya adaptasi antara manusia dengan lingkungan yang dipengaruhi oleh teknologi, ekonomi, sosial, dan politik (Sugiarti,dkk., 2019:70). Demikian pula dalam novel Mata dan Manusia Laut memberikan sebuah gambaran masyarakat suku Bajau bahwa dalam pengaruh modern saat ini masyarakat suku Bajau masih tetap bertahan dengan gaya hidup tradisional karena sistem kepercayaan yang telah diyakini sejak zaman nenek moyang sampai saat ini. Adanya pengaruh modernisasi tidak sepenuhnya tradisi nenek moyang dilupakan begitu saja.

\section{Budaya Kepercayaan (Tradisi Tidak Pergi Melaut Saat Purnama Tiba)}

Selain tradisi duata, masyarakat suku Bajau juga memiliki tradisi lain yaitu larangan untuk tidak pergi melaut saat bulan purnama tiba. Mengapa demikian ?. Masyarakat suku Bajau meyakini bahwa pada saat bulan purnama seluruh dewa yang ada di laut turun untuk melindungi ikan-ikan yang sedang berkembang biak saat bulan purnama. Hal tersebut dapat dilihat dari kutipan dibawah ini.

Mereka melihat bulan sebagai penanda waktu kapan ikan bisa ditangkap. Jangan menangkap ikan saat bulan terang. Begitu salah satu pelajaran pertama yang sudah dibagikan turun menurun. Anak seusia Bambulo pun sudah tahu tentang aturan itu. Bagi orang Sama, itu adalah larangan langsung dari penguasa semesta yang tak boleh dilanggar (Madasari, 2019:33).

Bulan terang yang dimaksud dalam kutipan novel di atas adalah bulan purnama. Masyarakat suku Bajau memiliki kepercayaan bahwa tidak boleh pergi melaut saat bulan purnama. Masyarakat suku Bajau mengetahui bahwa pada saat bulan purnama, seluruh ikan yang ada di laut sedang bertelur untuk menghasilkan ikan yang lebih banyak lagi dan masyarakat suku Bajau mepercayai bahwa pada saat ikan bertelur seluruh dewa laut turun ke laut untuk melindungi telur-telur ikan dari segala gangguan.

Larangan yang berlaku pada masyarakat suku Bajau tentunya tidak hanya sekedar larangan untuk mematuhi dewa laut, akan tetapi juga demi pemenuhan kebutuhan seharihari masyarakat suku Bajau. Keseharian masyarakat suku Bajau menggantungkan hidupnya pada ekosistem laut, sebagai masyarakat pesisir mereka tidak jauh dengan mata pencaharian mencari ikan. Untuk dapat memiliki baju baru, makan, dan keperluan yang lain masyarakat suku Bajau harus pergi mencari ikan terlebih dahulu, semakin banyak ikan yang diperoleh maka semakin banyak pula keuntungan yang mereka peroleh. Jadi, dapat dikatakan bahwa semua aturan dan pantauan tersebut bertujuan untuk memenuhi kebutuhan hidup masyarakat suku Bajau sehari-hari. Selaras dengan pendapat Sugiarti 
yang mengatakan bahwa keseluruhan aktivitas mata pencaharian manusia dilakukan atas dasar kebutuhan manusia untuk mempertahankan hidup dengan bekerja sesuai dengan pilihan masing-masing (Sugiarti, dkk 2019:80).

\section{Tradisi Kepercayaan Terhadap Lummu}

Selain memiliki kepercayaan terhadap roh atau makhluk ghaib. Masyarakat Suku Bajau juga memiliki kepercayaan terhadap hewan yang mereka percayai sebagai makhluk suci. Lummu, lummu adalah lumba-lumba yang dianggap sebagai makhluk suci bagi orang Sama (masyarakat Suku Bajau) sebagai utusan dari dewa laut. Melalui Lummu, masyarakat Suku Bajau dapat melihat tanda-tanda yang berupa tanda akan datangnya rezeki atau tanda akan datangnya bahaya. Hal tersebut dapat dilihat melalui kutipan berikut ini :

Semua orang Sama selalu menuruti petunjuk lummu. Mereka tak pernah menyakiti Lummu. Berbagai ikan mereka tangkap dan mereka santap, tapi tidak pernah mereka menangkap dan memakan Lummu (Madasari, 2019:39).

Berdasarkan data di atas, suku Bajau merupakan salah satu suku di Indonesia yang sampai saat ini masih berperilaku tradisional, yaitu dengan mempercayai segala kepercayaan yang dibawa oleh nenek moyang secara turun menurun baik kepada makhluk gaib maupun hewan sekaligus. Masyarakat suku Bajau masih percaya akan halhal yang menurut zaman modern seperti ini sudah tidak masuk akal. Akan tetapi hal tersebut tidak membuat masyarakat suku Bajau tertinggal dengan kehidupan masyrakat pesisir lainnya yang ada di Indonesia. Sejalan dengan pemikiran Umar (2019:117) sistem etika, adat, dan budaya yang dimiliki oleh masyarakat suku Bajau terbukti mampu membuat masyarakat suku Bajau dapat bertahan hidup dan selaras dengan yang lainnya.

Melestarikan lingkungan laut tentunya tidak hanya manjaga laut dari pencemaran lingkungan, akan tetapi juga harus menjaga seluruh komponen yang ada di dalamnya seperti hewan laut dan terumbu karang. Tradisi dan kepercayaan yang ada pada masyarakat suku Bajau terhadap Lummu atau lumba-lumba mengajarkan masyarakat yang lain untuk tidak mengeksploitasi ikan yang ada di laut secara besar-besaran apalagi terhadap ikan yang dilindungi karena keberadaannya yang langka. Perlindungan terhadap lumba-lumba yang dilatarbelakangi oleh kepercayaan masyarakat suku Bajau bukan berarti tidak bermakna bagi kehidupan manusia yang lain, hal tersebut dapat dijadikan sebuah pelajaran untuk semua manusia agar melakukan pemanfaatan dan kesejahteraan hewan laut terutama lumba-lumba dengan baik. (Fanny, 2018)

Lumba-lumba merupakan salah satu hewan yang dilindungi dari kesalahgunaan pemanfaatan. Dewasa ini banyak sekali pertunjukan-pertunjukan yang memanfaatkan lumba-lumba untuk melakukan atraksi. Banyak diantara lumba-lumba disiksa demi menuruti apa yang diinginkan sang pawing untuk menghasilkan pertunjukan yang luar biasa. Bahkan mereka terpaksa untuk tinggal dan berada di dalam kolam dengan kandungan klorin yang berbahaya bagi mereka, hal ini sudah termasuk suatu tindak 
pidana penyiksaan (Fanny, 2018:3). Perilaku seperti itu tidak bisa dibiarkan terusmenerus, karena dalam Undang-Undang Nomor 18 Tahun 2009 tentang Peternakan dan Kesehatan Hewan, kesejahteraan hewan adalah segala urusan yang berhubungan dengan keadaan fisik dan mental hewan menurut ukuran perilaku alami hewan yang perlu diterapkan dan ditegakkan untuk melindungi hewan dari perlakuan setiap orang yang tidak layak terhadap hewan yang dimanfaatkan manusia

Sehubungan dengan hal itu telah terbukti bahwa hubungan lingkungan dengan manusia menghasilkan sebuah kebudayaan yang terikat sangat erat.. Manusia dalam menjalani kehidupan sehari-hari pada suatu lingkungan tidak terlepas dari kebudayaan yang ada untuk dijadikan sebagai tatanan atau aturan dalam bertindak atau berperilaku. Apabila seseorang menentang sebuah kebudayaan yang telah turun menurun menjadi sebuah keyakinan dan kepercayaan, maka seseorang tersebut akan medapatkan balasan sesuai dengan apa yang dilakukan. Hubungan manusia dalam adaptasi pemenuhan kebutuhan akan melahirkan sebuah perubahan, dan perubahan tersebut ada kaitannya dengan kebudayan yang sesuai dengan kebutuhan manusia (Sugiarti dan Candra, 2019).

\section{Relasi antara manusia dan lingkungan}

Manusia dan lingkungan merupakan dua komponen yang memiliki hubungan sangat erat. Lingkungan bagi manusia menjadi salah satu komponen yang sangat penting. Karena tidak hanya sebagai tempat tinggal, bagi manusia lingkungan juga dapat dijadikan sebagai pemenuhan kebutuhan dalam kehidupan sehari-hari.

Relasi antara lingkungan dan manusia dalam novel Mata dan Manusia Laut digambarkan melalui beberapa petualangan yang dialami oleh tokoh Bambulo dalam novel. Bambulo adalah seorang anak yang memiliki kemahiran berenang dan menyelam di dalam air. Bambulo merasa sudah memiliki ikatan yang erat dengan laut itu sendiri, sehingga dalam kehidupan sehari-hari Bambulo sangat menjaga terhadap ekosistem laut yang bagaimana telah diajarkan oleh orang tua sebagai petuah yang turun-menurun dari nenenk moyang. Tidak hanya Bambulo, seluruh masyarakat suku Bajau juga sangat menjaga dan patuh terhadap alam khususnya laut. Hal tersebut dilakukan oleh masyarakat suku Bajau karena mereka percaya apabila alam tidak dimanfaatkan dengan baik dan tanpa tanggung jawab maka akan menimbulkan sebuah petaka untuk masyarakat itu sendiri. Adapun data yang menggambarkan relasi antara manusia dengan lingkungan dalam novel Mata dan Manusia Laut berikut ini :

"Jangan bicara sembarangan," kata Ladasi. "Kita tak pernah mengebom ikan. Orang Bajo tak pernah mengebom ikan. Kita hanya mengangkut barang dangangan. Beda dengan itu!" "Orang Sama tidak pernah ada yang mengebom ikan,” kata Bambulo. "Itu pantangan” (Madasari, 2019:214).

Berdasarkan data di atas relasi antara manusia dengan lingkungaan tergambarkan melalui pelestarian yang dilakukan manusia terhadap ekosistem laut. Tidak ada satupun masyarakat suku Bajau yang berani untuk merusak ekositem laut dengan pemanfaatan 
tanpa adanya tanggung jawab. Relasi yang terjadi antara masyarakat suku Bajau dengan lingkungan sudah sangat erat sehingga timbul rasa untuk saling menjaga satu sama lain.

Ekosistem memiliki peran yang sangat penting bagi kehidupan manusia. Karena di dalam ekosistem laut terdapat beberapa sumber daya alam yang dapat dimanfaatkan oleh manusia. Tentunya manusia sebagai pengguna, tidak hanya memanfaatkan sumber daya alam tanpa rasa tanggung jawab. Rasa tanggung jawab dan peduli terhadap lingkungan harus ada pada setiap diri manuisa. Pelestarian tersebut dapat dilakukan dengan memperhatikan budaya sebagai acuan untuk melakukan sesuatu terhadap alam sehingga tidak akan muncul terjadinya penyimpangan sistem ekologi budaya.

Krisis ekosistem di Indonesia saat ini harus diperhatikan. Banyak sekali pemanfaatan ekosistem terutama laut dilakukan secara besar-besaran dengan legel. Hal itu tidak bisa dibiarkan secara terus-menerus, karena menyebabkan kerusakan ekosistem yang mengakibatkan berkurangnya sumber daya alam. Selain berkurangnya kebutuhan, mengambil ikan dengan cara yang tidak layak juga dapat mengakibatkan seluruh kehidupan yang ada di dalam laut ikut mati.

Sesuai dengan teori yang sebelumnya dipaparkan, bahwa dalam kajian ekokritik terdapat model kajian yang berperspektif etis. Kajian yang berperspektif etis sendiri meupakan sebuah kajian yang dapat menggambarkan nilai-nilai kearifan terhadap lingkungan. Hal tersebut sesuai dengan data di atas. Relasi antara manusia, budaya, dan lingkungan masyarakat suku Bajau dapat memberikan gambaran nilai-nilai kearifan terhadap lingkungan. Kaerifan terhadap lingkungan itu sendiri berwujud prinsip-prinsip moral berupa rasa hormat terhadap alam, sikap tanggung jawab terhadap alam, solidaritas kosmis, prinsip kasih sayang dan kepedulian penuh terhadap alam, perinsip tidak merugikan alam, prinsip hidup sederhana dan selaras dengan alam, prinsip keadilan, prinsip demokrasi, dan prinsip integritas moral (Bandingkan Tylor, 1986; Naess, 1993;Singer, 1993;Keraf,2010).

Berdasarkan dengan teori tersebut, masyarakat suku Bajau sudah memenuhi prinsip-prinsip moral yang ada dalam kearifan lingkungan. Masyarakat suku Bajau memiliki pantangan untuk tidak mengambil ikan dengan cara mengebom merupakan sebuah contoh prinsip bahwa masyarakat suku Bajau memiliki sikap tanggung jawab, tidak mau merugikan alam, dan yang pasti kepedulian yan penuh terhadap lingkungan laut. Selain itu masyarakat suku Bajau juga memegang prinsip yang menunjukkan bahwa mereka memiliki kasih sayang penuh terhadap lingkungan yaitu dengan cara tidak memakan Lummu (lumba-lumba) sebagai hewan yang hidup di laut dan dipercayai telah menjadi pelindung bagi orang sama.

\section{Dampak Relasi antara Manusia, dan Lingkungan}

Relasi yang terjalin antara manusia dan lingkungan pastinya akan memiliki dampak yang negatif maupun positif. Berkenaan dengan hal itu, dalam novel Mata dan Manusia Laut juga menggambarkan adanya relasi antara manusia dengan lingkungan 
yang berdampak positif maupun negatif. Ada beberapa dampak yang dialami oleh beberapa tokoh dalam novel mengenai pemanfaatan dan ketergantungannya terhadap sumber daya laut terutama ikan. Pemanfaatan terhadap sumber daya laut secara langsung maupun tidak langsung akan berdampak pada lingkungan hidup. Pemanfaatan dan pengelolahan sumber daya alam tentunya memiliki sebuah tujuan yaitu untuk menyejahterakan kehidupan masyarakat terutama masyarakat lokal yang berada pada daerah sumber daya alam (Triaputri da Ledy, 2017).

Dalam novel Mata dan Manusia Laut relasi antara para tokoh dengan lingkungan sekitar (laut) berjalan dengan baik, sehingga dapat dikatakan dampaknya bersifat postitf. Selain itu, dalam novel Mata dan Manusia Laut juga ditemukan sebuah fakta bahwa sumber daya laut terutama ikan memiliki pengaruh besar bagi kehidupan masyarakat suku Bajau. Adapun kutipan dalam ovel yang yang menggambarkan peristiwa tersebut diantaranya adalah:

Untuk semua kebutuhan itu, orang Sama butuh uang sebanyak-banyaknya uang. Atol adalah jawaban untuk itu semua. Hanya di Atol mereka bisam mendapatkan banyak uang.

Kamu masih bingung apa itu atol?

Orang-orang kebanyakan menyebutnya karang, karena memang atoll adalah karang. Tapi ia karang yanv panjang, melingkar serupa cincin, membentuk semacam danau atau laguna raksasa. Di laguna itulah, ikan dan berbagai hewan laut hidup. Jumlahnya melimpah, taka ak habis ealau semua orang Sama mengambilnya setiap hari (Madasari, 2019:32-33)

Semua kebutuhan orang Sama akan terpenuhi dengan adanya atol yang dikenal menjadi suatu tempat penghasil ikan terbanyak. Jika dilihat dengan perkembangan zaman yang semakin pesat, membuat kebutuhan orang Sama pun juga berkembang. Mereka juga ingin punya parabola agar gambar televisi mereka jadi jelas, mereka juga ingin membeli baju baru saat pasar malam diadakan, dan yang paling penting mereka juga ingin memiliki banyak perhiasan sebagai symbol kebanggan dari mereka. Keseharian warga suku Bajau khususnya kampung Sama bergantung pada hasil laut yang melimpah, tentunya sebagai manusia yang baik dan peduli terhadap lingkungan, orang Sama tidak hanya memanfaatkan laut begitu saja tanpa tanggung jawab. Mereka memiliki aturan-aturan dan pantangan untuk menjaga kelestarian lingkungan laut. Segala aturan dan pantangan tersebut nantinya pasti akan memiliki dampak baik itu negative maupun positif tergantung seseorang yang melakukannya terhadap aturan dan pantangan itu.

Melalui tokoh utama Bambulo dan Matara penggambaran dampak relasi manusia dengan lingkungan budaya dapat diketahui dengan terselamatnya Bambulo dan Matara ketika mendapat musibah di tengah laut dan masuk ke dalam wilayah yang dinamakan Kampung Masalembo. Kampung Masalembo ini merupakan sebuah kampung yang berada di dasar laut dan dihuni oleh orang-orang yang tidak sengaja terperangkap di sana serta makhluk hidup laut yang lain. Kampung Masalembo tersebut dalam kehidupan 
nyata atau kehidupan sehari-hari tidak jauh berbeda dengan segitiga bermuda. Adapun kutipan dalam novel yang menggambarkan peristiwa tersebut diantaranya adalah :

Semua awak kapal tertawa. Salah satu dari mereka menepuk-nepuk bahu Bambulo. "Untung kamu selamat, Bambulo. Bisa jadi pealut hebat nanti kalu sudah besar (Madasari, 2019:204)

Musibah yang dialami oleh tokoh Bambulo dan Matara dalam novel menjadi salah satu pengalaman yang paling mengesankan bagi mereka. Dalam novel diceritakan bahwa mereka terperangkap dalam sebuah wilayah yang dipercaya oleh suku Bajau tidak ada yang dapat kembali ke alam sebelumnya apabila sudah masuk dalam daerah tersebut (Kampung Masalembo). Tetapi pemikiran itu tidak berlaku kepada Bambulo dan Matara. Bambulo dan Matara masuk ke kampung Masalembo disambut sangat baik oleh penghuni Masalembo yang terdiri dari manusia-manusia laut dan makhluk hidup laut lainnya. Mereka saling bercerita bagaimana mereka bisa sampai di kampung Masalembo. Hingga suatu ketika Bambulo dan Matara meminta tolong kepada mereka untuk bisa kembali ke kampung halaman mereka yang sebenarnya, karena ada keluarga yang menunggu mereka. Salah satu dari manusia laut itu megatakan kalau Bambulo tidak akan bisa kembali lagi ke dunia yang sebenarnya, akan tetapi berkat usaha Bambulo yang selama ini sangat peduli dan menjaga terhadap ekosistem laut dan dewa laut mengetahui hal itu, akhirnya dewa Laut menghendaki mereka untuk kembali ke dunia yang sebenarnya dengan selamat.

Jika dikaitkan dengan kehidupan saat ini, kampung Masalembo memang benar adanya. Kawasan ini lebih dikenal dengan sebutan segitiga Masalembo. Kawasan ini dikenal dengan kawasan yang paling membahayakan bagi pengguna transportasi laut. Sering terjadi kecelakaan transportasi laut pada daerah ini yang disebabkan oleh dua faktor yaitu pada bulan Desember-Februari disebabkan karena pengaruh West Monson dan Arlindo arus laut dari Belahan Bumi Utara dan pada sekitar bulan Juli-September disebabkan karena pengaruh hanya Arlindo arus laut dari belahan bumi selatan (Harcici, 2017). Dengan begitu masyarakat berpendapat barang siapa yang masuk dalam kawasan tersebut kecil kemungkinan untuk bisa kembali lagi. Tapi tidak ada yang tidak mungkin di dunia ini jika Tuhan yang maha segalanya sudah berkehendak. Seperti petuah-petuah yang sudah biasa diucapkan mengenai hukum alam yaitu barang siapa yang menjaga alam maka alam juga akan menjaganya akan tetapi apabila alam digunakan tanpa tanggung jawab, maka alam akan mendatangkan sebuah petaka (Hariyono dan Aryati, 2018).

Berbicara mengenai hukum alam sama halnya membicarakan tentang dampak relasi antara manusia itu sendiri dengan lingkungan. Seperti yang sudah dibahas sebelumnya, bahwa dampak tersebut ahmhmda yang bersifat positif ada pula yang bersifat negatif. Setiap orang memiliki latar belakang dan cara yang berbeda untuk membentuk relasi dengan lingkungan alam. Latar belakang berdasarkan budaya misalnya, seperti yang telah digambarkan dalam novel Mata dan Manusia Laut. Mereka memiliki budaya untuk tidak pergi melaut pada saat bulan purnama, karena mereka mengetahui pada saat bulan purnama seluruh ikan-ikan yang ada di dalam laut mengalami 
proses bertelur untuk menghasilkan ikan yang lebih banyak. Untuk mencegah berkurangnya jumlah ikan karena gagal bertelur, masyarakat suku Bajau sepakat untuk tidak pergi melaut saat bulan purnama selain itu mereka juga percaya dan meyakini pada saat bulan purnama seluruh dewa laut turun ke laut untuk melindungi ikan-ikan yang bertelur tersebut. Akan tetapi aturan itu dilarang oleh tokoh Bambulo dan Matara yang pada akhirnya mereka mendapat musibah dari tindakan mereka sendiri. Adapun kutipan dalam novel yang menggambarkan perstiwa tersebut diantaranya adalah:

Matara dan bambulo sama-sama mendongak. Bulan kian dekat dengan mereka. Besar sekali. Empat atau bahkan lima kali lebih besar disbanding bulan purnama yang biasa dilihat Matara.

Sampan bergoyang ke kiri dan kanan. Kian lama kian keras. Air laut berloncatloncatan, menjulur-julur seperti lidah yang ditarik ke atas. Makin lama lidahlidah itu makin tinggi dan lebar, mereka seakan berlomba-lomba untuk bisa menyentuh permukaan bulan (Madasari, 2019:93).

Pada kutipan di atas mendeskripsikan bahwa telah terjadi kelalaian dalam pelaksanaan budaya yang berada pada masyarakat pesisir khususnya suku Bajau. Berawal dari rasa penasaran Matara terhadap keberadaan Atol yang menjadi pusat mata pencaharian orang-orang Sama, karena di Atol terdapat banyak sekali ikan-ikan. Demi membuktikan keberadaan Atol kepada Matara, Bambulo dengan semangat mengajak dan mengantar Matara menuju Atol tanpa memperhatikan kondisi alam yang terjadi pada malam itu. Bulan bersinar sangat terang tidak seperti biasanya, ini menandakan bahwa bulan purnama telah tiba, pantangan bagi masyarakat suku Bajau untuk pegi melaut. Anak sesusia Bambulo pasti sudah mengetahui akan pantangann itu, karena sejak kecil anak seusia Bambulo sudah diperkenalkan beberapa budaya dan tradisi termasuk laranganlarangan yang harus dihindari dan tidak boleh dilakukan. Entah lupa atau hanya ingin memenuhi nafsunya Bambulo sekejap lupa akan petuah-petuah yang telah diajarkan, di tengah perjalanan menuju Atol Bambulo dan Matara mengalami sebuah peristiwa yang cukup dahsyat sehingga membawa mereka ke dalam laut yang paling dasar.

Hal ini memperjelas dampak negatif yang diperoleh dan dirasakan ketika seorang manusia melanggar terhadap kepercayaan daerahnya. Alam dan budaya membuktikan betapa besar pengaruhnya terhadap kehidupa manusia dalam novel Mata dan Manusia Laut. Hubungan antar manusia pun dapat rusak karena keinginan manusia dalam memaksimalkan nasfsu ingin tahunya (Sakinah, dkk., 2019:14). Pesan ekologis dalam penelitian ini adalah manusia dapat merasakan dampak yang lebih besar dalam kehiduapan apabila manusia merawat dan memanfaatkan alam serta memiliki rasa tanggung jawab secara sadar dan tidak serakah. 


\section{SIMPULAN}

Masyarakat Suku Bajau memiliki beraneka ragam bentuk budaya. Budaya-budaya tersebut tidak jauh dari kepercayaan dan ekosistem masyarakat pesisir. Bentuk-bentuk budaya masyarakat suku Bajau terdiri dari tradisi Duata, tradisi tidak pergi melaut saat purnama, tradisi kepercayaan terhadap Lummu, dsb.

Adanya budaya antara manusia dengan lingkungan menimbulkan sebuah persoalan-persoalan yang terjadi dari relasi keduanya. Hal itu bisa disebut dengan ekologi budaya. Ekologi budaya yang terdapat dalam novel Mata dan Manusia Laut karya Okky Madasari digambarkan melalui petualangan-petualangan yang dialami oleh tokoh utama dalam novel serta menimbulkan berbagai persoalan akibat melanggar budaya kepercayaan masyarakat suku Bajau sebagai masyarakat pesisirs. Petualanganpetualangan teresebut merupakan sebuah bentuk relasi antara manusia dengan lingkungan. Setiap relasi yang terjadi menimbulkan dampak positif maupun negatif.

Sistem budaya dan kepercayaan yang sudah ada sejak zaman nenek moyang tidak harus sepenuhnya dilupakan akibat perkembangan zaman yang modern seperti saat ini. Budaya tradisional dijadikan sebagai pondasi dalam melakukan segala sesuatu terutama untuk menjaga kelestarian ekosistem sekitar. Apabila hal tersebut dilakukan, maka akan tercipta sebuah keseimbangan antara manusia dengan lingkungan sehingga menghasilkan ekologi budaya yang baik.

\section{REFERENSI}

Arne, N. (1993). Ecology, Community, and Lifestyle. Cambridge: Cambridge Univ. Press.

Artanto, Y. K. (2017). Bapongka, Sistem Budaya Suku Bajo dalam Menjaga Kelestarian Sumber Daya Pesisir. 12.

Endaswara, S. (2016). Metodologi Penelitian Ekologi Sastra : Konsep, Langkah dan Terapan. Yogyakarta: CAPS.

Fanny, V. (2018). Perlindungan Lumba-lumba sebagai Satwa Langka yang Dilindungi dari Tindakan Penempatan dan Atraksi Hiburan yang Tidak Sesuai. Jurnal Hukum Adigama, 4.

Hamzah, S. (2013). Pendidikan Lingkungan. Bandung: PT. Refika Aditama.

Keraf, S. A. (2010). Etika Lingkungan Hidup. Jakarta: Penerbit Buku Kompas.

Koentjaraningrat. (2002). Pengantar Ilmu Antropologi. Jakarta: Rineka Cipta.

Kristiawan, N. (2017). Pola Adaptasi Ekologi Budaya Tiga Komunitas di Jambi. Bhumi, 189-200.

Madasari, O. (2019). Mata dan Manusia Laut. Jakarta: PT Gramedia Pustaka Utama.

Naess, A. (1993). Ecology, Community, and Lifestyle. Cambridge: Cambridge Univ. Press. 
Putra, C. W., \& Sugiarti. (2019). Ekologi Budaya dalam Novel Lanang karya Yonathan Rahardjo. Atavisme, 113-127.

Sakina, F. N., Juanda, \& Saguni, S. S. (2019). Relasi Antara Manusia dan Alam pada Novel Genduk Karya Sundari Mardjuki (Sebuah Kajian Ekokritik). 1-17.

Sudikan, S. Y. (2016). Ekologi Sastra. Lamongan: Pustaka Ilalang Group

Sugiarti. (2018). Lingkungan Budaya (Ekobudaya) dalam Sastra Peretas Nilai-nilai Luhur Bangsa. Prosiding Senabasa.

Sugiarti, Andalas, E. F., Saraswati, E., \& Kusniarti, T. (2019). Ekologi Budaya Studi Ekologi dalam Bingkai Kajian Ssatra Interdisipliner. Malang: UMM 